\title{
SYNTHESIS AND RESOLUTION OF THE OPTICAL ISOMERS OF THIENCYNONATE HYDROCHLORIDE
}

\author{
HE LIU*, LI-PING LIU, JING-LI WANG, BO-HUA ZHONG, AND KE-LIANG LIU \\ No.7 Department, Beijing Institute of Pharmacology and Toxicology, Beijing 100850. P. R. China
}

\begin{abstract}
Thiencynonate hydrochloride ( $N$-methyl-9 $\alpha$-(3-azabicyclo[3,3,1]nonanyl)-2'-cyclopentyl-2'- hydroxyl-2'-thienylacetate, I·HCl), an new muscarinic receptor antagonist, was synthesized and its enantiomers were obtained form the optical pure of demethylation product II. A convenient resolution method of demethylation product II has been developed with $N$-p - toluenesulfonylglutamic acid as the resolution reagent. The structures of I and II were elucidated by X-ray analysis.
\end{abstract}

Keywords: Thiencynonate hydrochloride, optical resolution, anticholinergic Drug

\section{INTRODUCTION}

Design, development, and marketing of new chiral drugs are now a major theme in the drug chirality research and industry. ${ }^{1}$ In 1996, the FDA announced it would consider further incentives for developing single isomer drugs for their better pharmacokinetics prosperity, safety, and tolerability. ${ }^{2}$ Our recent drug candidate: N-MethylL-9 $\alpha$-(3-azabicyclo[3,3,1]nonanyl)-2'-cyclopentyl2'-hydroxyl-2'-thienylacetate hydrochloride (Thiencynonate hydrochloride, $\mathbf{I} \cdot \mathrm{HCl}$, Chart 1$)$, is a potent selective $\mathrm{M}_{1}$ antagonist. It is composed of a tertiary hydroxyl acid as a key component as like many of the muscarinic receptor antagonists. It exhibits classical antimuscarine side effects, such as dry mouth. The preliminary biology results suggest that the $(S)$-(-)-configuration of the tile compound display an improved therapeutic profile compared to its racemic counterpart. The optical resolution of racemates via diastereoisomeric salt formation is a common way for the preparation of optical isomers. ${ }^{3,4} \mathrm{We}$ didn't found a suitable acid for the resolution of $\mathbf{I}$ due to the weak alkalescence of the tertiary $\mathrm{N}$ structure. In our efforts to have a production of the enantiopure, we synthesized the demethylation compound II to enhance the alkalescence. We found that inclusion crystallisation with $\mathrm{N}$ - $p$-toluenesulfonylglutamic acid(TSGA) as a chiral host is an effective method for the resolution of II with high enantiomeric excess.

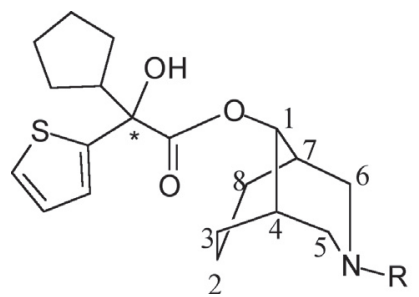

(I) $\mathrm{R}=\mathrm{CH}_{3} \quad$ Thiencynonate (II) $\mathrm{R}=\mathrm{H}$

\section{EXPERIMENTAL}

General

All the reagents for syntheses were commercially available and used without further purification or purified by standard methods prior to use. Melting points were determined using a RY-1 apparatus and are uncorrected. Elemental analyses were performed on a Perkin-Elmer $240 \mathrm{C}$ analyzer. ${ }^{1} \mathrm{H}-\mathrm{NMR}$ spectra were measured in $\mathrm{CDCl}_{3}$ using a multinuclear FT-NMR spectrometer ARX300 (Bruker). Mass spectra were obtained from Micromass ZabSpec and API3000 instruments. The enantiomeric excess of the title compound was determined by HPLC. Condition of HPLC: Hypersil BDS column and $\beta$-cyclodextrin as chiral mobile phase additive, methanol: acetonitrile: $\mathrm{KH}_{2} \mathrm{PO}_{4}\left(0.075 \mathrm{~mol} \cdot \mathrm{L}^{-1}\right)$ : $\mathrm{H}_{2} \mathrm{O}=25: 2: 60: 18$ as elute. $\alpha$-Cyclopentyl- $\alpha$-hydroxyl- $\alpha$-thienylacetic acid was synthesized by addition of Grignard reagents to diethyl oxalate as described in the literature. ${ }^{8}$

Synthesis

9a-(N-Methyl-3-azabicyclo[3,3,1]nonanyl)-2'-cyclopentyl-2'-hydroxyl-2'thienylacetate I

Methyl $\alpha$-cyclopentyl- $\alpha$-hydroxyl- $\alpha$-thienylacetate $(2.6 \mathrm{~g}, 11 \mathrm{mmol})$ and 3 -azabicyclo[3,3,1]nonan-9 $\alpha$-ol $(1.5 \mathrm{~g}, 10 \mathrm{mmol})$ were dissolved in anhydrous n-heptane $(100 \mathrm{~mL}), \mathrm{NaH}(0.5 \mathrm{~g}$ assay $80 \%)$ was added. The solution was reflux for 3 hours. The solvent was removed under reduced pressure; the residue was dissolved in ether $(150 \mathrm{~mL})$, washed with water and brine, dried over anhydrous sodium sulfate, and concentrated to dryness. I was purified by flashchromatography (chloroform/methanol, 9:1) and isolated as an oil (3.1g, 79\%). Anal. Calcd for $\mathrm{C}_{20} \mathrm{H}_{20} \mathrm{NO}_{3} \mathrm{~S}$ : C, 66.08; $\mathrm{H}, 8.04 ; \mathrm{N}, 3.85$. Found: $\mathrm{C}, 66.14 ; \mathrm{H}$, 7.99; N, 3.91. ${ }^{1} \mathrm{H} \mathrm{NMR}\left(\mathrm{CDCl}_{3}\right) \delta 7.24(\mathrm{~m}, 1 \mathrm{H}, \mathrm{Ar}-\mathrm{H}), 7.12(\mathrm{~m}, 1 \mathrm{H}, \mathrm{Ar}-\mathrm{H})$, $7.08(\mathrm{~m}, 1 \mathrm{H}, \mathrm{Ar}-\mathrm{H}), 4.81(\mathrm{~s}, 1 \mathrm{H}, 1-\mathrm{OH}), 4.12(\mathrm{~s}, 1 \mathrm{H},-\mathrm{OH}), 3.01(\mathrm{~m}, 3 \mathrm{H}), 2.55$ $(\mathrm{m}, 1 \mathrm{H}), 2.25(\mathrm{~m}, 2 \mathrm{H}), 2.15\left(\mathrm{~s}, 3 \mathrm{H}, \mathrm{N}-\mathrm{CH}_{3}\right), 1.95(\mathrm{~m}, 2 \mathrm{H}), 1.40-1.85(\mathrm{~m}, 13 \mathrm{H}$ cyclopentyl-H and nonanyl-H). MS (ESI): $364.2(\mathrm{M}+1)^{+}$.

$9 \alpha$-(N-trichloroethylformyl-3-azabicyclo[3,3,1]nonanyl)-2'-cyclopentyl2'-hydroxyl-2'-thienylacetate.

A mixture of I (3.6g, 10mmol) and 2,2,2-trichloroethylchloroformate $(2.5$ $\mathrm{g}, 12 \mathrm{mmol}$ ) in $50 \mathrm{~mL}$ anhydrous benzene was heated under reflux for 20 hours. After evaporation of the solvent and excessive 2,2,2-trichloroethylchloroform ate, the residual oil was added to a solution of $50 \mathrm{~mL}$ of $25 \% \sim 28 \% \mathrm{NH}_{3} \cdot \mathrm{H}_{2} \mathrm{O}$ and $50 \mathrm{~mL}$ of ether. The organic solution was washed with two $10 \mathrm{~mL}$ portion of saturated brine, and dried over anhydrous magnesium sulfate. The solution evaporated under reduced pressure to give the product $4.7 \mathrm{~g}$ ( $91 \%$ yield) as a yellow oil. ${ }^{1} \mathrm{H}$ NMR $\left(\mathrm{CDCl}_{3}\right) \delta 7.21(\mathrm{~m}, 1 \mathrm{H}, \mathrm{Ar}-\mathrm{H}), 7.08(\mathrm{~m}, 1 \mathrm{H}, \mathrm{Ar}-\mathrm{H}), 7.03$ $(\mathrm{m}, 1 \mathrm{H}, \mathrm{Ar}-\mathrm{H}), 4.79(\mathrm{~s}, 1 \mathrm{H}, 1-\mathrm{OH}), 4.64\left(\mathrm{~s}, 2 \mathrm{H},-\mathrm{OCH}_{2} \mathrm{CCl}_{3}\right), 04.05(\mathrm{~s}, 1 \mathrm{H},-$ $\mathrm{OH}), 3.02(\mathrm{~m}, 3 \mathrm{H}), 2.51(\mathrm{~m}, 1 \mathrm{H}), 2.20(\mathrm{~m}, 2 \mathrm{H}), 1.93(\mathrm{~m}, 2 \mathrm{H}), 1.86(\mathrm{~m}, 1 \mathrm{H})$, 1.42-1.80 (m, 12H, cyclopentyl-H and nonanyl-H). MS (ESI): $524.2(\mathrm{M}+1)^{+}$.

9 a-(3-azabicyclo $[3,3,1]$ nonanyl $)-2^{\prime}$-cyclopentyl-2'-hydroxyl-2'thienylacetate. rac-II

A solution of the yellow oil product in $50 \mathrm{ml}$ glacial HOAc and $3.5 \mathrm{~g}$ Zinc dust was stirred for 5 hours at room temperature. After removal of the Zinc by filtration, the filtrate was basified with concentrated $\mathrm{NaOH}$ and extracted with three 50-ml portions of ether. The solution evaporated under reduced pressure to give rac-II $2.8 \mathrm{~g}\left(80 \%\right.$ yield) of colorless solid, MS (ESI): $350.4(\mathrm{M}+1)^{+}$. m.p. 131-133 $\square$. Anal. Calcd for $\mathrm{C}_{10} \mathrm{H}_{27} \mathrm{NO}_{3} \mathrm{~S}: \mathrm{C}, 65.30 ; \mathrm{H}, 7.79 ; \mathrm{N}, 4.01$. Found: $\mathrm{C}$, 65.51; H, 7.61; N, 4.18. ${ }^{1} \mathrm{H}$ NMR $\left(\mathrm{CDCl}_{3}\right): 7.26(\mathrm{~m}, 1 \mathrm{H}, \mathrm{Ar}-\mathrm{H}), 7.15(\mathrm{~m}, 1 \mathrm{H}$, Ar-H), 6.95(m, 1H, Ar-H), 4.97(s, 1H, 1-H), 4.12(br, 1H, -OH), 3.11(m, 5H), $2.86(\mathrm{~m}, 1 \mathrm{H}), 2.20(\mathrm{~m}, 1 \mathrm{H}), 2.00(\mathrm{~m}, 1 \mathrm{H}), 1.32-1.90(\mathrm{~m}, 14 \mathrm{H}$, cyclopentyl-H and nonanyl-H).

\section{Optical resolution of rac-II}

A solution of rac-II $(3.5 \mathrm{~g}, 10 \mathrm{mmol})$ and $L-N$-toluenesulfonylglutamic acid (TSGA) $(3.0 \mathrm{~g}, 10 \mathrm{mmol})$ in anhydrous ethanol $(150 \mathrm{~mL})$ was kept at 50 for $12 \mathrm{~h}$. After being cooled to room temperature, a 1:1 inclusion complex $(S)-(-)-\mathbf{I I} \cdot L$-TSGA was obtained as colorless crystals. Recrystallization of the salts from ethanol three times gave pure inclusion crystals. The inclusion complex was basified with $2 \mathrm{~mol} \cdot \mathrm{L}^{-1} \mathrm{NaOH}$ and extracted with ether $(50 \mathrm{~mL}$ $\times 3$ ) and dried over anhydrous magnesium sulfate. The solution evaporated under reduced pressure to give optical pure $(S)-(-)-$ II. $0.99 \mathrm{~g}(56 \%$ yield $)$. $[\alpha]=-$ $32.1^{\circ}\left(\mathrm{c}=2\right.$, ethanol), $98.2 \%$ e.e.. m.p. $132-133 \square$. Anal. Calcd for $\mathrm{C}_{19} \mathrm{H}_{27} \mathrm{NO}_{3} \mathrm{~S}$ : C, 65.30; H, 7.79; N, 4.01. Found: C, 65.42; H, 7.73; N, 4.09.

The mother liquor was concentrated in vacuo and the residue was make alkaline with $2 \mathrm{~mol} \cdot \mathrm{L}^{-1} \mathrm{NaOH}$. The ester was extract with ether $(50 \mathrm{~mL} \times$ 3 ) and dried over anhydrous magnesium sulfate. After evaporation of the solvent, a solution of $D$ - $N$-toluenesulfonylglutamic acid $(4.0 \mathrm{~g}, 13 \mathrm{mmol})$ in anhydrous ethanol $(100 \mathrm{~mL})$ was added and the salt $(R)-(+)-\mathbf{I I} \cdot D$-TSGA formed was purified in same process as described above. $(R)-(+)-$ II was obtained by basified the salt $1.05 \mathrm{~g}(60 \%$ yield $)$. $[\alpha]=+32.5^{\circ}(\mathrm{c}=2$, ethanol), $99.1 \%$ e.e. 
m.p. 132-133 $\square$. Anal. Calcd for $\mathrm{C}_{19} \mathrm{H}_{27} \mathrm{NO}_{3} \mathrm{~S}$ : C, 65.30; H, 7.79; N, 4.01. Found: C, 65.44; H, 7.82; N, 4.06.

(S)-(-)-I and $(R)-(+)-\boldsymbol{I}$

$(S)-(+)-\mathbf{I}$ and $(R)-(-)-\mathbf{I}$ were synthesized by methylation of enantiopure II. $(R)-(+)$-II or $(S)-(-)-$ II $(0.97 \mathrm{~g}, 2.8 \mathrm{mmol})$ was dissolved in $30 \mathrm{~mL}$ anhydrous ethanol and $10 \mathrm{Ml}$ anhydrous $\mathrm{Et}_{2} \mathrm{O}, 0.5 \mathrm{~mL} \mathrm{CH}_{3} \mathrm{I}(3.2 \mathrm{mmol})$ and $1 \mathrm{~g} \mathrm{~K}_{2} \mathrm{CO}_{3}$ were added. The mixture was stirred for 3 hours at room temperature. Additional 0.5 $\mathrm{mL}$ was added and then stirred for 24 hours. After removal of the $\mathrm{K}_{2} \mathrm{CO}_{3}$ by filtration, the filtrate was evaporated under reduced pressure and purified by flash-chromatography (chloroform/methanol, 9:1). (S)-(-)-I and $(R)-(+)-\mathbf{I}$ were isolated as an oil.

$(S)-(-)-\mathbf{I}[\alpha]=-7.3^{\circ}\left(\mathrm{c}=0.5, \mathrm{CHCl}_{3}\right), 99.1 \%$ e.e.. ${ }^{1} \mathrm{H} \mathrm{NMR}\left(\mathrm{CDCl}_{3}\right): \delta$ 7.24(m, 1H, Ar-H), 7.12(m, 1H, Ar-H), 6.98(m, 1H, Ar-H), 5.05(s, 1H, 1-H), 4.08( (br, $1 \mathrm{H},-\mathrm{OH}), 3.82(\mathrm{~m}, 2 \mathrm{H}), 3.15(\mathrm{~m}, 2 \mathrm{H}), 2.93\left(\mathrm{~s}, 3 \mathrm{H}, \mathrm{N}-\mathrm{CH}_{3}\right), 2.92(\mathrm{~m}$, $2 \mathrm{H}), 2.32(\mathrm{~s}, 1 \mathrm{H}), 2.21(\mathrm{~s}, 1 \mathrm{H}), 1.98(\mathrm{~m}, 2 \mathrm{H}), 1.42-1.86(\mathrm{~m}, 12 \mathrm{H}$, cyclopentyl-H and nonanyl-H). MS (ESI): $364.2(\mathrm{M}+1)^{+}$.

$(R)-(+)-\mathbf{I}[\alpha]=+7.2^{\circ}\left(\mathrm{c}=0.5, \mathrm{CHCl}_{3}\right), 99.1 \%$ e.e.. ${ }^{1} \mathrm{H} \mathrm{NMR}\left(\mathrm{CDCl}_{3}\right): \delta 7.23$ (m, 1H, Ar-H), $7.11(\mathrm{~m}, 1 \mathrm{H}, \operatorname{Ar}-\mathrm{H}), 7.01(\mathrm{~m}, 1 \mathrm{H}, \operatorname{Ar}-\mathrm{H}), 5.05(\mathrm{~s}, 1 \mathrm{H}, 1-\mathrm{H})$, 4.09(br, 1H, $-\mathrm{OH}), 3.82(\mathrm{~m}, 2 \mathrm{H}), 3.11(\mathrm{~m}, 2 \mathrm{H}), 2.97\left(\mathrm{~s}, 3 \mathrm{H}, \mathrm{N}-\mathrm{CH}_{3}\right), 2.94(\mathrm{~m}$, 2H), $2.31(\mathrm{~s}, 1 \mathrm{H}), 2.18(\mathrm{~s}, 1 \mathrm{H}), 1.92(\mathrm{~m}, 2 \mathrm{H}), 1.40-1.85(\mathrm{~m}, 12 \mathrm{H}$, cyclopentyl-H and nonanyl-H). MS (ESI): $364.2(\mathrm{M}+1)^{+}$.

The oil was dissolved in $\mathrm{Et}_{2} \mathrm{O}, 1 \mathrm{M} \mathrm{HCl} / \mathrm{Et}_{2} \mathrm{O}$ was dropped slowly. The mixture was stirring at room temperature for $1 \mathrm{~h}$. The precipitation was filtered and washed with cooled $\mathrm{Et}_{2} \mathrm{O}$, dried under vacuum. Thiencynonate hydrochloride was obtained as a white precipitate.

\section{RESULTS AND DISCUSSION}

Optical resolution of $\mathbf{I}$ was performed as outlined in Scheme 1. Racemate I can be conveniently synthesized by methyl $\alpha$-cyclopentyl- $\alpha$-hydroxyl- $\alpha$ thienylacetate and 3-azabicyclo[3,3,1]nonan-9 $\alpha$-ol. In order to demethylate of I, carbamate would be desirable. 2,2,2-trichloroethyl carbamate can be removed with zinc dust in glacial HOAc at room temperature. ${ }^{5}$ A $1: 1$ ratio of rac-II and $L-(-)-N$-( $p$-methylphenylsulfonyl) glutamic acid(TSGA) were mixed in the anhydrous ethanol at $50^{\circ} \mathrm{C}$, then cooled and an inclusion complex of $(S)$-(-)-II- $L$-TSGA was separated out. The precipitated inclusion complex were recrystalized three times in the anhydrous ethanol. (S)-(-)-II was obtained through alkaline hydrolysis of the resolved acid. The mother liquor was concentrated and alkaline. The residue was added to a solution of $D$-TSGA and then $(R)-(+)-$ II was obtained through alkaline hydrolysis of $(R)-(+)-$ II $\cdot D$-TSGA salts. $(S)-(+)-$ and $(R)-(-)-\mathbf{I}$ were synthesized by methylation of enantiopure II with $\mathrm{CH}_{3}$.

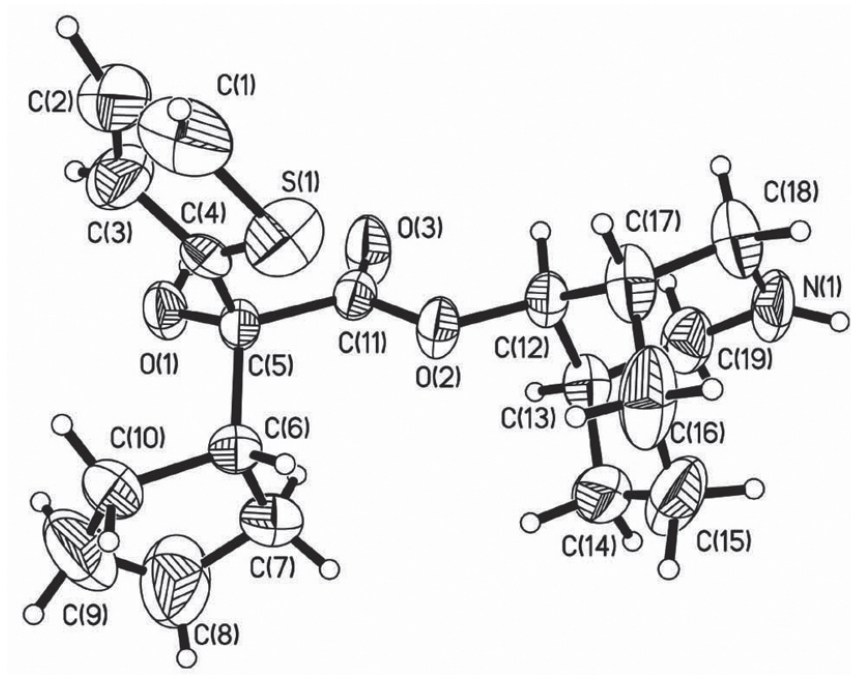

(a)
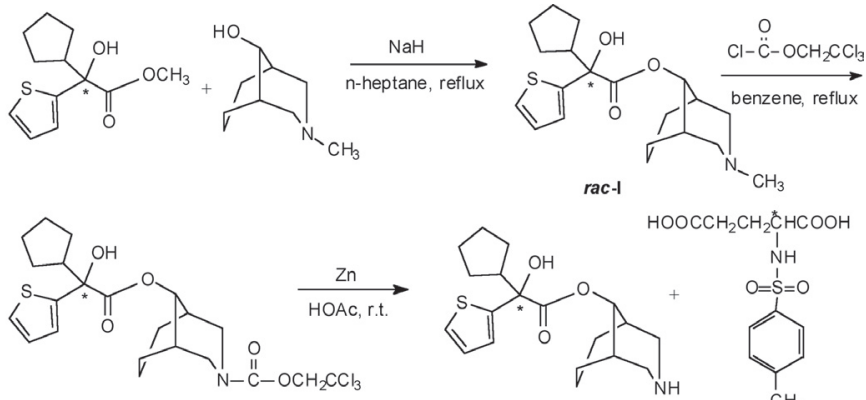

$\mathrm{HOOCCH} \mathrm{CH}_{2} \mathrm{C} \mathrm{HCOOH}$

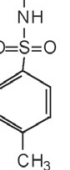

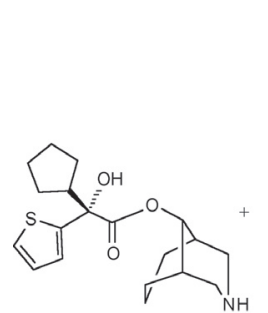

(S)-II

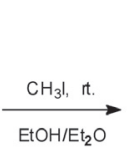

Sheme 1.

The colorless crystals of $(R)-(+)-\mathbf{I I}$ and $(R)-(+)-\mathbf{I}$ suitable for X-ray analysis were obtained by recrystallization from dichloromethane solution. The X-ray ORTEP structure of the two compounds with atomic labelling is shown in Fig. 1. X-ray structure analytical data showed that the two compounds are similar composed of a 3-azabicyclo[3,3,1]nonane structure and a tertiary hydroxyl acid that adopted $R$-configuration. The bicyclic structure adopts a twin-chair conformation, this is the most favored conformation for the bicyclo[3,3,1]nonane ring system. ${ }^{6,7}$

\section{(III) $\mathrm{Cl}(1)$}

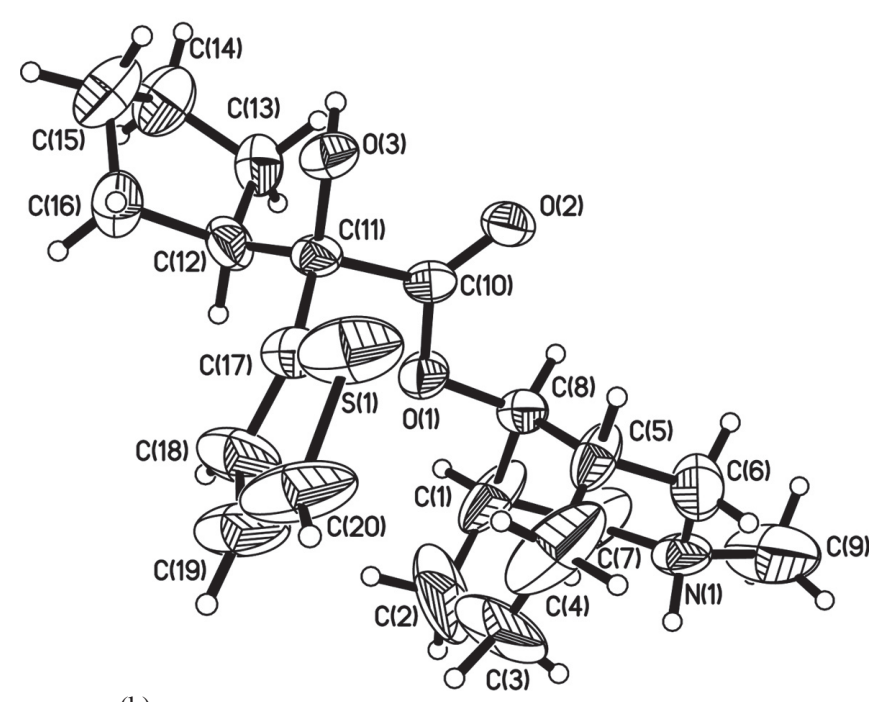

(b)

Figure 1. The crystal structures of (R)-II and (R)-I. 


\section{ACKNOWLEDGEMENTS}

This work was financially supported by the National Natural Science Foundation of China (No. 20302015).

\section{REFERENCES}

1. (a) H. Caner, E. Groner, L. Lery and I. Agranat, Durg Discovery Today 2004, 9, 105. (b) A.M. Rouhi, Chem. Eng. News 2003, 81, 45.

2. A. Richards and R. McCague, Chem. Ind. 1997, 422.

3. D. Kozma, M. Ács and E. Fogassy, Tetrahedron 1994, 50, 6907.
4. T. Vries, H. Wynberg, E. van Echtenm, J. Koek, W. ten Hoeve, R.M. Kellogg, Q.B. Broxterman, A. Minnaard, B. Kaptein, S. van der Sluis, L. Hulshof and J. Kooistra. Angew. Chem. Int. Ed.. 1988, 37, 2349.

5. (a) M.G. Reinecke and R.G. Daubert, J. Org. Chem. 1973, 38, 3281. (b) T. B. Windholz and D.B.R. Johnston, Tetrahedron 1967, 2555.

6. D. Kunaran, M.N. Ponnuswamy, G. Shanmugam, S. Ponnuswamy, R. Jevaraman, K. Shivakuman and H.-K. Fun, Acta. Cryst. 1999, B55, 793.

7. L. Vijayalakshmi, V. Parthasarathi, M. Venkatraj and R. Jeyaraman, Acta. Cryst. 2000, C56, 1240.

8. (a) J.S. Ninita and H.S. Mosher, J. Org. Chem. 1981, 46, 211. (b) F. Jordan, J. Org. Chem. 1994, 59, 5763. 